Article

\title{
Religion: A Source of Fundamentalism or A Safeguard Against It?
}

\section{Michał Gierycz}

Institute of Political Science and Public Administration, Cardinal Stefan Wyszyński University in Warsaw, Wóycickiego 1/3, bud.23, 01-938 Warsaw, Poland; m.gierycz@uksw.edu.pl

Received: 29 January 2020; Accepted: 18 February 2020; Published: 26 February 2020

check for updates

\begin{abstract}
This article contributes to critical reflection on the political study approach towards the relations between religion and fundamentalism. In the context of post-secularism, in which the cognitive and moral role of religion for politics is quite widely recognised, the aim is to discuss three hypotheses. The first one argues that, contrary to what the majority of the subject's literature maintains, fundamentalism is not only a strictly religious phenomenon, but a specific attitude, able to evolve equally well on both religious and secular foundations. The second one implies that secularisation encourages, at least to an equal degree, both profane and religious fundamentalist tendencies. The third thesis asserts that religion, in its nature, constitutes a potential safeguard against fundamentalism. In the course of analysis, the pertinence of the above hypotheses are generally demonstrated. However, it is also indicated that the third point constitutes a mid-range theorem, accurately describing the contemporary specificity of Christianity, and especially Catholicism.
\end{abstract}

Keywords: fundamentalism; religion and politics; secularism; political science; Islam; Catholicism; Protestantism

\section{Introduction}

The title of this article may appear provocative. Quite commonly in literature on fundamentalism, authors present it as a strictly religious phenomenon (Pratt 2020; Cowden and Sahdal 2017; Rausch 2015; Ozzano 2009; Marczewska-Rytko 2007; Armstrong 2000; Bruce 2000). The problem is that such a view, quite widespread within the political science of religion, which explicitly or implicitly takes the secularisation paradigm as an axiom (Gierycz 2019, pp. 42-45), is far from self-evident and requires critical analysis. There is much to suggest that (1) fundamentalism is not a strictly religious phenomenon, but rather a specific way of thinking and acting which may thrive in secular just as well as in religious soil; (2) secularisation enhances secular just as much as religious fundamentalist tendencies; (3) religion is, by its very nature, a potential safeguard against fundamentalism. Whether or not it does play such a role in real life is related, to a large extent, to the character of a particular religion. This article discusses these three hypotheses in an attempt to contribute to a critical reflection on the way the relationship between religion and fundamentalism is viewed in the political science of religion.

The problem with any research on fundamentalism is, however, that it seems to be a fuzzy concept, lacking any explicit "semantic contours" (Bielefeldt and Heitmeyer 1998, p. 11, cf. Riesebrodt 2004). It is worth noting that even though the notion of fundamentalism first emerged in the beginning of the 20th century in the context of disputes within American Protestantism, it did not become prevalent in political rhetoric or academic discourse until the end of the 1970s and the revolution in Iran (Haynes 2010). Consequently, the term "fundamentalists" is nowadays used to refer, almost in the same breath, to American Protestants of the end of the 19th century, their distant cousins gathered around the Moral Majority in the second half of the 20th century, and the Islamists of the turn of the 20th and 21st 
centuries. The very fact that groups so distant from one another, both timewise and in terms of the ends and the means used to achieve them, are classified into a single category seems to substantiate the claim that there are some semantic problems involved in the notion. One can hardly fail to notice that in political discourse the notion of fundamentalism is often treated as a stigmatising term, aimed at discrediting a political opponent (Janicki and Władyka 2015). Consequently, in everyday usage it does not belong so much to the parlance of political science but to that of politics, playing an ideological rather than an explanatory role. In view of all of these considerations, before going into a more detailed analysis of the relationship between religion and fundamentalism it is necessary to explain how the notion may be understood in political science and to at least sketch out a theory of fundamentalism which could be used when describing and explaining political phenomena. To this end, it seems advisable to go back to the sources: to the historical context in which the notion of "fundamentalism" first appeared.

\section{Two Interpretations of the Term "Fundamentalism"}

The term "fundamentalist" was first used in the United States to describe the proponents of a series of Protestant publications entitled The Fundamentals, which defended a literal interpretation of the Scripture. Their publication was a reaction to the progressing domination, especially among the Lutherans and the Calvinists, of a historical and critical exegesis of the Bible, with its characteristic scientism and positivism. With an aim of "liberating" the Biblical text of anything that could not be reconciled with a rationalist logic, critical exegesis in fact undermined the entire supra-rational dimension of the Revelation: anything that looked like a myth or referred to apparently miraculous phenomena (Schlegel 2003). In opposition to a modernist direction in biblical interpretation, in the years 1910-1915 a group of American Protestants published a series of booklets which, as announced by their title (The Fundamentals), defended "fundamental matters"; indisputable truths of the faith, opposing the modernist tendencies in Protestantism. The booklets discussed biblical and doctrinal issues (the salvific role of the cross, the resurrection of Jesus, the infallibility of the biblical text), as well as matters of worldview (booklets aimed against the Catholic Church, socialism, Darwinism, etc.). Protestants supporting The Fundamentals believed in a literal interpretation of the Scripture, ruling out any symbolic or moral reading of biblical texts (Schlegel 2003). One frequently cited example of this approach was the claim that the world's creation in six days should be unquestioningly accepted. In fact, this issue became the source of a social depreciation of the fundamentalist stance following the Scopes Monkey Trial of 1925. The trial also significantly affected the character of the term "fundamentalism" itself; even though initially it did not include a value judgement, after the Scopes Monkey Trial it acquired a pejorative ring.

The fundamentalist experience at the turn of the 19th and 20th century can be read in two ways which lead to two approaches of fundamentalism today. On the one hand, it may be stressed that fundamentalism was initially an objection to a relativisation of the Revelation. In this perspective, fundamentalism may be understood as an approach which looks for absolute, universal foundations of knowledge (Kijas 2010), and thus as the opposite of relativism. Understood this way, fundamentalism refers to the cognitive attitude to reality. In this approach, which may be called substantial, the notion of "fundamentalism" does not contain a value judgement. According to Ernest Gellner, fundamentalism understood in epistemic terms in fact represents, in both its religious and its rationalist version, one of the two possible (the other being relativism) essential worldviews. In this perspective, a religious fundamentalist is simply someone who accepts religion in its full form as the foundation of knowledge about reality, without attempting to "bend" or relativize, compromise or mitigate (Sacks 1991), one who represents "strict adherence" to religious doctrine (Rausch 2015, p. 29) while believing that its doctrine presents the fundamental truth about God and the human condition. A secular version of such an understanding of fundamentalism would be a rationalist fundamentalism which continues the tradition of the Enlightenment revolution in science and which is an option for all those who do not have religious faith, but who reject the intellectually insubstantial offer of relativism (Gellner 1992). 
While the approach to fundamentalism outlined above may help introduce some order into philosophical or theological discussions, it does not seem satisfactory from the perspective of a political scientist. In the political perspective, the notion of fundamentalism seems to mean something else. In order to make this difference evident, it is enough to point out that if religious fundamentalism were to be defined as "consistent religiousness" in the context of the secular age, this would mean a "fundamentalist affiliation" of both Ayatollah Khomeini and Pope Francis, or-referring to groups-the Pentecostal charismatic movements and organisations like Gush Emunim. The explanatory value of this approach is-as far as political perspective is concerned-practically null, since in this way a fundamentalist is both someone who accepts violence as a form of political struggle and one who rejects such methods, one who respects human rights and one who does not, one who strives for absolute power and one who makes no such claims, etc. The only sensible conclusion in such an approach would appear to be the confession made by Steve Bruce, who says in the summary of his book that "we do not need an explanation of fundamentalism as such" (Bruce 2000, p. 122).

If we can see, however, that there is a significant difference between the Muslim Brotherhood and the Fraternities of Jerusalem, we must conclude that there is a specific type of religiousness or, more broadly, perception of reality different from its other forms. In this approach, our attention is focused not so much on the content of beliefs or worldviews, but on the form in which they are articulated and experienced. In the context of the historical beginnings of fundamentalism, its other interpretation could thus be derived not so much from the fundamentalists' objection to the relativisation of the Revelation, but rather from the form in which this objection was expressed, characterised-at least in popular opinion-by such features as limited discursiveness or animosity towards interlocutors. This approach does not relate fundamentalism to the matter from which it emerges, but focuses on the mindset, way of acting, and goals pursued by fundamentalists. Consequently, it is not about the content based on which such an attitude develops, but the attitude itself that is decisive in determining whether we are dealing with fundamentalism or not. Defined on the ground of social sciences methodology, this other, formal understanding of fundamentalism, which stays in respect to proposals presented in Fundamentalism Project by Almond et al. (1995), recognises that first of all "what matters is not what people believe in, but how they defend their beliefs...and how they substantiate them" (Wnuk-Lipiński 2004, p. 273). In this approach, it is emphasised, therefore, that fundamentalism is an attitude.

\section{Characteristics of a Fundamentalist Attitude}

Considering fundamentalism as an attitude means understanding it as a way of approaching the world, a way of "evaluating" reality. This evaluation, according to the findings of social psychology, consists of three elements: cognitive, emotional (affective), and behavioural (Aronson et al. 1994). Consequently, fundamentalism understood as an attitude entails that fundamentalists primarily differ from the "rest of the world" by a specific way of thinking (a "fundamentalist mindset") which then determines the trajectories of a fundamentalist approach to the world, both emotionally and behaviourally. Such an understanding of fundamentalism would seem to be rather useful in the perspective of political science research.

\subsection{Cognitive Aspects}

A striking feature in the presented studies of fundamentalist groups and in the works of their founders is their sense of possessing, that is of having a complete understanding, of truth. Steven Bruce calls it a sense of "certainty" (Bruce 2000, p. 15). For example, in the theory of Sajjid Kutb, a leading ideologist of the Muslim Brotherhood, power originally belongs exclusively to God, who designed the right vision of the world. However, since God does not wield his power directly, in real life it should be held by those who have discovered and properly understood this truth. The "knowing" is embodied by warrior monks, who are the only bearers of truth (Was 2006). They are an elite in the proper sense of the word: the only competent subjects who define social and individual good. Bassam Tibi points out that such an attitude, with its characteristic intellectual absolutism, represents an important trait of 
fundamentalists who rule out any critical reflection on their own views (Tibi 1997). Ultimately, every decision and determination made by the "enlightened" is, as it were, sanctioned by God. For the record, this does not only apply to fundamentalist Muslim groups. For example, Karen Armstrong points to the intellectual absolutism of Christian fundamentalists. In this context, she refers to Carl McIntire, founder of the Bible Presbyterian Church in the USA, who radically condemned Christians who "did not subscribe to his theology" (Armstrong 2000, p. 216). A similar trait of fundamentalism has been identified in the Hindu tradition by Piotr Kłodkowski who, like Eric Hobsbawm, points out that Hindu fundamentalism represents "a contemporary interpretation of the ancient religion" (Kłodkowski 2006, pp. 425-26), linked to an ethnically understood national idea. It is not present in the Vedas themselves, but rather in their contemporary interpreters. The claim to truth, which is in fact a claim to inerrancy, should therefore be considered the first element of a fundamentalist mindset. Let us note that the truth professed by religious fundamentalists may radically differ, and its sources may just as well be the Vedas, the Quran, or the Bible. Irrespective of the material from which fundamentalism develops, it is always based on the fundamentalists' belief that they have achieved, so to speak, epistemic fullness, the only correct understanding of the Revelation and of God's will for people here and now.

A consequence of this attitude to truth is-however paradoxical as it may seem-an ambivalent stance on orthodoxy. As pointed out by scholars of fundamentalism, a fundamentalist does not embrace his religious tradition as a whole. Quite on the contrary, he only upholds those fragments that he accepts himself and which make him stand out from the "mainstream." In the case of Sajjid Kutb, mentioned above, this can be seen, for instance, in the special role played by the notion of tali' $a$, i.e., the need for a select avant-garde of crusading missionaries and emphasis on the category of jihad, which was not as significant in the traditional interpretation of Islam. This selectiveness of interpretation is in fact a reconstruction and a transformation of religious tradition (Jansen 1997). Fundamentalists are not concerned about faithful observance of orthodoxy. Oppositely, "they thrive by demarching themselves from others within their own faith-tradition" (Harrison 2008, p. 9). In a sense, they are the ones who create the "true" doctrine, selectively choosing from their religion that which is submitted to politicisation and absolutisation (Tibi 1997, p. 152). The selectiveness of a fundamentalist affects not only his religious (or ideological) tradition, but also the world he rejects. Bassam Tibi describes this process while referring to the example of Islamic fundamentalism: "the bisection of modern civilization stems from the desire of its islamisation by instrumentally adopting its material achievements, while at the same time unconditionally rejecting its fundamental man-centered view of the world...fundamentalists are not traditionalists ... they are against modern civilization, but they are not against its instrumental, that is to say, technical and scientific achievements. Quite on the contrary: they want to understand them in order to be able to better fight against their enemies" (Tibi 1997, pp. 35, 43). The airplane attack on the World Trade Center in 2001 seems to be a particularly dramatic evidence of this kind of logic, which currently can be observed in contemporary Islamists, bred on Kutb's writings, believing themselves to be the just ones who stand up (through jihad) against the unjust ones (e.g., the political leaders of the countries they operate in) (Haynes 2010, p. 165).

The belief in their own inerrancy in a way forces fundamentalists to adopt a black-and-white view of the world. As pointed out by Edmund Wnuk-Lipiński, irrespective of the grounds on which fundamentalism develops, it is always characterised by the conviction that "the part of the world which is outside of the fundamentalist movement is contaminated, sinful, and doomed to condemnation. Only within the world controlled by the fundamentalist movement can there be spiritual purity, truth, and good" (Wnuk-Lipiński 2004, p. 278). Consequently, in the logic of religious fundamentalists researchers see a reflection of the Manichean approach to reality where the forces of darkness (the world) are confronted by the forces of light (fundamentalists) (Bruce 2000).

\subsection{Affective and Behavioural Aspects}

The elements of a fundamentalist mindset described above (absolutism, selectiveness, Manicheism) translate into fundamentalist emotions and behaviours. It is characteristic that in almost all works 
on fundamentalism, the term is defined by what it repudiates (Gellner 1992; Bruce 2000). Thus, fundamentalism (e.g., in the case of Islamic or Christian fundamentalism) is described as a reaction to the modern world and the processes of modernisation and secularisation (Was 2006). In the case of Hindu fundamentalism, a sense of threat from other religious traditions (Islam or Christianity) is emphasised (Kłodkowski 2006). On the affective level, fundamentalists would thus be characterised by a sense of threat (fear) and by opposition, sometimes developing into hostility, to what is recognised as alien and standing in contradiction to the truth they possess about the right arrangement of human affairs (Haynes 2010; Harrison 2008). At the same time, fundamentalism-in all its varieties-helps restore a sense of security and commitment within one's own group, generating also high social control. Since the group of fundamentalists is the only bearer of truth which enables the introduction of an ideal order, those who belong to it truly feel they are fortune's favourites-God's avant-garde (Hallermann et al. 2019, p. 105f).

This specific emotional polarisation connected with the cognitive perspective described above, forces them, on the behavioural level, into activism in an attempt to change the world in accordance with their own views. A religious fundamentalist who believes that he possesses knowledge about the appropriate religious, social, and political order expected by God, and who objects to the actual condition of the world, puts himself in a position of both a prophet and a king. He reveals the "divine ideal" and feels responsible for its implementation. Therefore, he does in fact want the Messianic promises to be fulfilled in this world and strives to make the Kingdom of God arrive here on earth. Jonatan Jansen adds that "in such a Kingdom the literal truth of the revealed divine book will be a minor, self-evident detail" (Jansen 1997, p. 6). This somewhat sarcastic comment is very significant. A fundamentalist—as previously mentioned-is not an "orthodox" by nature. On the contrary, almost by definition he (re)defines the doctrine. And the purpose of this reinterpretation is to make the expected order come true in this world. Whether we are dealing with Islamic or Hindu fundamentalism, the striking fact is that a fundamentalist is first concerned not with what is "up above" but with what is "down below." In this sense, it is said, for example, that "Islamic fundamentalism is both fully politics and fully religion." (Kłodkowski 2006, p. 99; cf. Tibi 1997). Similarly, it would be difficult to separate the spiritual and the political dimensions in Hindu fundamentalism (Kłodkowski 2006, p. 415). Transformation of the world, commitment to making the ideal world come true, is the proper goal of fundamentalists whose efforts are always marked by a trait of utopia. Consequently, on the one hand, fundamentalists are prepared to reject anything they recognise as "alien," even if this means universal values.

Perceiving themselves as "chosen group," God's avant-garde, means also that fundamentalists "believe that it is essential to the religious integrity that they distance themselves from those who have been deemed to have strayed from the one and only correct form of faith. Thus, fundamentalist groups, irrespective of their religious tradition, tend to form exclusive communities within which only those who share their beliefs and their lifestyle are welcome" (Harrison 2008, p. 9). Such an approach reduces their ability to establish alliances almost to zero (Wnuk-Lipiński 2004, p. 280).

The above brief outline of the aspects of a fundamentalist attitude based on analyses and studies of religious fundamentalism plainly shows that it is the formal approach to fundamentalism (focused on the characteristic features of the attitude rather than any particular views) that makes this notion sufficiently clear to be useful in analyses of social and political phenomena.

\section{Secular Fundamentalism}

When fundamentalism is treated as an attitude, this suggests, from the theoretical perspective, that the quite widespread conviction about the exclusively religious nature of fundamentalism needs to be corrected. Even though the analyses presented above, based on extensive literature on the subject, were focused on the religious forms of the fundamentalist attitude, it can hardly be concluded that any of its characteristic features (for example, a selective way of thinking, or a desire to change the world in accordance with one's own standards) are limited only to the religious attitude. Moreover, 
fundamentalists can see a threat in both secular and religious stances. In view of the above conclusions, we need to ask about the existence of secular fundamentalisms. If the theory of fundamentalism outlined above is correct, the fundamentalist approach should then be also possible to detect on secular grounds.

\subsection{Classical and Contemporary Manifestations of Secular Fundamentalism}

A review of studies on the political phenomena of the 20th and the 21st century, including in particular secular religions (Aron 1962; Voegelin 2000), leaves practically no doubt that the above statement is substantiated. One of the most well-respected Polish sociologists, Edmund Wnuk-Lipiński, demonstrated the legitimacy of considering communism as a form of secular fundamentalism. In Świat międzyepoki, he showed that the communist logic includes all the symptoms of a fundamentalist attitude: the belief in possessing the truth, a selective approach to "sacred texts," rebellion against the existing order coupled with a commitment to creating an ideal world, worship of the leader, and hatred of the "enemies of the system," activism in striving to change the world, etc. (Wnuk-Lipiński 2004, pp. 281-84). It is characteristic that already in 1917 Lenin believed that his "prime task is to re-establish what Marx really taught" (Lenin 1918), and therefore-in a typically fundamentalist way-demanded that everyone should accept his own as the only right interpretation of canonical texts, radically distancing himself from those who-also drawing on the teachings of Marx-were not revolutionary enough, in his opinion, and in fact falsified Marxism by "deceiving the people." For even though the writings of the author of Das Kapital were the communists" "sacred" texts, they were not so in every interpretation. The right one, just like in the case of the interpretation of Islam by the ideologists of the Muslim Brotherhood, was that of the current leader and his entourage.

In fact, as has been pointed out by Eric Voegelin, who demonstrated the gnostic sources of Marx's thought, Marxism itself was a theory aimed at "incarnating the logos in the world by means of revolutionary human action" (Voegelin 1975, p. 275) thus representing a specific, fundamentalist type of mindset. Voegelin points out that Marx transformed Hegel's contemplative gnosis into practical action, becoming "a Paraclete in the best medieval, sectarian style, a man in whom the logos had become incarnate and through whose action in the world mankind at large would become the vessel of the logos" (Voegelin 1975, p. 276). Without going into a more detailed discussion of a fundamentalist character of "political religions," insightfully analysed inter alia in the classical works of Erich Voegelin (2000) or Raymond Aron (1962), it is worth noting, however, that secular fundamentalist tendencies are found not only in "total phenomena."

John Gray points out that radical Islamists are essentially not very different from communists or neoliberals in terms of the structure of their mindset. He says, "In the new world as envisaged by Al Qaeda power and conflict have disappeared. This is a figment of the revolutionary imagination, not a prescription for a viable modern society; but in this the new world envisioned by Al Qaeda is no different from the fantasies projected by Marx and Bakunin, by Lenin and Mao, and by the neoliberal evangelists who so recently announced the end of history" (Gray 2007, p. 4). The same thought can also be found in the writings of Agnieszka Kołakowska, who describes several examples illustrating how the ideologisation of certain categories of contemporary political discourse due to political correctness in fact hinders any rational debate. She says that a good exemplification of the "anti-empirical, anti-rational, and anti-scientific approach is the issue of 'globalisation'": the "evil" of globalisation, just like the "good" of sustained development, is a kind of dogma which "must not be questioned" (Kołakowska 2010, pp. 21-24). The conviction that one possesses the truth and the ultimate knowledge of the proper order of things results-in accordance with the fundamentalist paradigm -in open animosity of the "politically correct" to those who think otherwise, and in a radical suppression of anyone who questions "the one and only truth." As pointed out by Matthieu Bock-Cote, "progressivism inherently includes the temptation of fanaticism and paves the way for the practice of presenting 'reactionaries' as public enemies, as enemies of the human race...it sanctions intolerance by justifying it with noble motives" (Bock-Cote 2017, p. 302). 
The question is whether the above claims are sufficiently substantiated - whether in the aspirations of Karl Marx to finally set the course of history towards salvation, and in the "politically correct" activities aimed at silencing certain views, ideas, or groups, a similar logic can be found. In other words, can it be demonstrated that in both cases we are dealing with a belief in the "inerrancy" of the elite who possess the formula for an ideal order; an exclusive patent on knowledge of the proper form and sense of socio-political institutions and relations, i.e., with an analogous fundamentalist potential.

\subsection{Fundamentalism as an Element of Modern Politics}

Studying the dispute accompanying modern politics, in his book entitled A Conflict of Visions. Ideological Origins of Political Struggles Thomas Sowell (2007) takes as his starting point the experience of two revolutions: American and French. The former brought about the formation of a constrained government, which respected the presence of religion in the public sphere; the latter, being in a way a harbinger of the totalitarianisms of the 20th century, organised an open war against Christianity combined with a state terror, which was perceived as - let us quote Robespierre-" "a consequence of the general principle of democracy applied to country's most urgent needs" (Carr 1951, p. 154).

Where did this difference come from? Sowell believes it had its source in two diametrically different metapolitical views, understood as ideal types in Weber's sense: constrained and unconstrained (Sowell 2007). The former attempts to reconcile conflicting interests and opinions about what may be considered as social good, while the latter strives to implement a knowable and identifiable social good as an overriding value (for example, the Marxist ideal of a classless society) (Vanberg 1987, p. 547). The former, referring to the intuition that civilisation is but a thin layer superimposed over layers of barbarism, sees "postponing the end" as the "basic structure of all human politics," which seems to be here "a watchful keeping in check of those tendencies which are conducive to exploding the "original chaos'" (Spaemann 2012, p. 275). The latter, inspired by the optimism of the Enlightenment, sees politics as a tool of constant progress: in a Promethean blast it wants to build a paradise on earth. While in the former perspective, social experiments may threaten the existence of humankind, in the latter there is no risk involved, since - behind man's back, so to say—an invisible hand will lead human history to a happy ending anyway. In the former perspective, the goal is to "postpone the end," while in the numerous versions of the latter- to "prepone" it.

A different perception and moderation of the dynamics of social processes results, according to Sowell, from a different concept of the political reason in the advocates of both visions. The proponents of the unconstrained vision believe that it is possible to find a rational answer to all problems and challenges, if only the forces of intelligence and of virtue could be made to prevail over ignorance and wickedness (Berlin 1950, pp. 351-85). Consequently, the unconstrained vision employs intellectual reflection to look for a solution of the political problem and establish some form of the ideal order. Every social change which is a step towards achieving this desired ideal should be preferred, no matter the cost (Sowell 2007, p. 29). In the course of the teleological process leading to social change, it is conditionally permissible to use violence, characteristic of revolutionary politics.

In the constrained vision, reason is treated with much more skepticism. Knowledge is conceived first of all as social experience, passed on in non-articulated forms of traditions, customs, habits, sentiments, feelings and behaviours; it is the everyday experience of people, succeeding in the Darwinian contest between that which works and that which does not. Consequently, knowledge is broadly accessible, but always shared. The advocates of constrained vision strongly believe that individual reason is much too insufficient to capture the diversity and take the right decisions. This gives rise to a politics of cautious evolution: since systemic rationality is more reliable than individual rationality, a reformer will respect the established customs and prejudices of the people, yet "will not disdain to ameliorate the wrong" (Sowell 2007, p. 27). A key category for the advocates of this vision is the compromise (trade-off) developed within the framework of systemic processes. One might say that imperfection is here understood as a perfect social solution. 
The belief that knowledge is an element which results in qualitative differences between people leads the advocates of an unconstrained vision to the conclusion that citizens of narrow horizons should submit to the leadership of the elites who cultivate the mind: philosophers or qualified experts. The special role of "the thinking people" or the "most enlightened and the best" was, according to Sowell (2007, p. 44), a central theme of the unconstrained vision for centuries. Consequently, its advocates placing decision-making rights in the hands of the "avant-garde" (social elite) whose members are, for some reason, more competent in identifying the knowable and achievable good. They are guaranteed - though it is not clear how—a privileged access to resources of virtue and reason. They act as a "surrogate" of the society, leading it toward "ever-higher levels of understanding and practice ... pending the eventual progress of mankind to the point where all can make social decisions" (Sowell 2007, p. 110). As pointed out by Bock-Cote, "the one who knows what a perfect society is, does not engage in political debates but multiplies educational efforts, and may, if necessary, resort to violence or censorship to prevent the expression of political opinions which challenge his idea of utopia or the meaning of history" (Bock-Cote 2017, p. 302).

Without entering into an in-depth analysis of unconstrained politics (cf. Gierycz 2017), it should be emphasised that Sowell's analysis leads us to the conclusion that the fundamentalist potential is deeply ingrained in one of the two ways of thinking about politics which are characteristic of modern Europe. It appears that the concept of unconstrained politics coincides with an observation made by John Paul II in Centesimus Annus: "When people think they possess the secret of a perfect social organization which makes evil impossible, they also think that they can use any means, including violence and deceit, in order to bring that organization into being" (John Paul II 1991, no. 25). Such an approach, the Pope points out, in fact turns politics into a "secular religion," "which operates under the illusion of creating paradise in this world." Evidently, it is not a coincidence that such kind of logic emerges when religion is negated, initiating - together with the French Revolution-the secularisation processes in Europe. It seems that although "the secularist and the sceptic have denounced Christianity first and foremost, because of its encouragement of fanaticism," Chesterton rightly noted that "religion can be swept out of the matter altogether, and still there are philosophical and ethical theories which can produce fanaticism enough to fill the world" (Chesterton 2017, p. 319).

Since at its roots secular fundamentalism is linked to the hope of a perfect world and is profoundly inherent to the modern understanding of politics in Europe, two questions need to be considered: (1) whether it is not the case that-grating the ambivalent role of religion in the development of fundamentalism, as discussed above (particularly in Section 2)—it is precisely (if not only) religion that represents an effective, "systemic" safeguard against such tendencies; (2) what features of religion make it a substratum for fundamentalism, and which of its characteristics make it a hedge, or a natural safeguard against fundamentalist tendencies.

\section{Secularisation and Fundamentalism}

When discussing essential factors contributing to the development of religious fundamentalisms, literature on the subject usually refers to the threat of modernisation and related secularisation, i.e., departure from the traditional, religious models and values (Harrison 2008; Armstrong 2004). This is to a large extent true, as it was shown, in the reference to the beginnings of the fundamentalist movement in the USA. The first fundamentalist Islamic group, the Muslim Brotherhood, similarly emerged in reaction to the rapid westernisation of Egypt as a result of British colonisation. Thus, it is claimed that fundamentalism is one of the side-effects of secularisation processes, a "rage" of religiousness, so to speak. In accordance with this hypothesis, fundamentalism is supposed to be a response (reaction) of religious people to religion being denied the right to a presence in the public space (Bruce 2000, p. 101), a "revenge of God" (Kepel 1994). The example of the Muslim Brotherhood, which identifies modernisation with secularisation and consequently looks for the sources of all social, economic and political crises in the Muslims' departure from the precepts of their faith, indicates that this hypothesis has a significant explanatory value. 
Nonetheless, it is also worth noting that in contemporary times it is true mostly when applied to the relationship between the West and non-Western cultures. Secularisation-being an essentially European, and to some extent Western, phenomenon-does not cause a special "irascibleness" of the religion prevailing in Western hemisphere. This is triggered, if at all, in different cultures, mainly Islam.

This does not undermine the significance of the hypothesis which sees in secularisation an important cause or context of fundamentalism in the West, for there is a deeper layer to it. As noted above, in the age of modernity, secular fundamentalisms have developed on an unprecedented scale, leaving their imprint in the modern era not only as political religions, but also as a deep-running current of understanding politics in the spirit of unconstraint. It is therefore worth considering whether this hypothesis does not also provide us with an answer regarding the sources of Western, secular fundamentalism.

When looking for what represents the novum in the intellectual climate of modernity, one can hardly ignore the radically secularising, great new narration initiated during the Enlightenment which replaced the hitherto prevailing Christian narration. As noted by Joseph Ratzinger, "[t]he Enlightenment attempted to define the essential norms of morality while claiming that they would be valid etsi Deus non daretur, even if God did not exist" (Ratzinger 2005, p. 354). This reflection has led to the invention of a "secular public space" and a "secular state" as an area of "pure power" organised by man "as though God did not exist" (Mazurkiewicz and Gierycz 2016, p. 136). Consequently, the sacrum has been finally removed from its central, pivotal place which had organised social life (Casanova 1994, pp. 11-39).

Once Providence was forced into "retirement," in a process profoundly linked to the Enlightenment belief that once mankind entered its adulthood and all "dogmas and formulas" became expendable (Kant 1784), the legitimacy of the religious narration about eternal happiness and paradise was undermined. This did not, however, eradicate the very idea of a perfect order from social consciousness. On the contrary, the emerging modernity lives and breathes the idea of perfection, with a sense-clearly visible in the writings of the Enlightenment luminaries-that it is just "a step away" from achieving the state of perfection in human affairs. This new hope probably first appeared in the writings of Francis Bacon, for whom "the restoration of the lost 'Paradise' is no longer expected from faith, but from the newly discovered link between science and praxis" (Benedict XVI 2007, no. 17). In the course of transformations that followed in subsequent ages, the source of hope is shifted from science to scientifically designed politics that-as exemplified in Marx's flagship work-"recognizes the structure of history and society and thus points out the road towards revolution, towards all-encompassing change" (Benedict XVI 2007, no. 20).

The process of secularising Christian hope in the West thus opens a gateway, to use Eric Voegelin's expression, to the process of immamentising the eschaton; to an attempt-by definition doomed to failure-at making the ideal world come true in the here and now, and to ultimately destroy all evil. This entails a huge fundamentalist potential. As Krzysztof Dorosz rightly points out: "as long as the apocalyptic awareness is rooted in faith, God's sovereignty is respected, leaving it up to him to choose the time and place of intervention. Man is only supposed to wait. If, however, the apocalypse becomes secularized, or if it penetrates the imagination of religious activists who usurp for themselves the prerogatives of God himself, it becomes a real power in the world" (Dorosz 2010, p. 23). Naturally, the usurpation of God's prerogatives is possible first of all when the true God is removed from sight. In this perspective, one can clearly see that the process of secularisation doubly, so to say, weakens the dam against fundamentalism. Not only does it generate in non-Western cultures movements of "angry religiousness," but also, in regard to the secularised world, leaves room for claims that the ideal world may be made to come true in the here and now, thus contributing to the emergence of secular fundamentalist concepts. In other words, in consequence of making God irrelevant for the world, modernity creates perfect conditions for replacing the hope of God's kingdom with the hope of a kingdom of man. 
The above conclusion reveals the special, irreplaceable role of religion as a safeguard against fundamentalism. Whether we understand religion as a set of beliefs and practices, or as a relationship with God, it is a way, which starts, to cite Max Scheler, "from something absolutely holy" (Scheler 1921). Consequently, by its very nature it situates man's natural longing for "a radical improvement ... in the relationship to a supra-empirical Reality" (Kłoczowski 2004, p. 1064). The matter is of key importance, since this need for a "radical improvement, a salvation," as indicated by Kłoczowski (2004) or Zdybicka (2006), is an anthropological, inherent to the human condition, need. If we realise that fundamentalism involves an attempt at actualising eschatological hopes in the temporal world, we must conclude that only religion can provide a systemic hedge against their immanentisation and warrants keeping an eschatological distance. Unless it is immanentised, it will contribute to a constructive involvement in matters of this world. Let us note the social and political significance of Christianity, which "did not bring a message of social revolution like that of the ill-fated Spartacus, whose struggle led to so much bloodshed ... Jesus, who himself died on the Cross, brought something totally different: ... an encounter with a hope stronger than the sufferings of slavery, a hope which therefore transformed life and the world from within" (Benedict XVI 2007, no.4), which was demonstrated, for example, in the eradication of slavery in Europe.

Obviously, experience shows that not every religion can or even does perform such a role, and not in all circumstances. In view of the above comments which show fundamentalism as a problem of the specific mindset related to an immanentisation of messianic hopes, it appears that the key variables which are worth discussing here are (1) a religion's attitude to reason, and (2) its attitude to the temporal world.

\section{Reason, Religion, and Fundamentalism}

Some researchers investigating the phenomenon of fundamentalism believe that religion generates fundamentalism due to its inherent claim that it carries the absolute truth (Armstrong 2000). The absolutist claims of religion, including its conviction about the right order of things, would, in accordance with this hypothesis, generate a great fundamentalist potential in religions placing a great deal of emphasis on orthodoxy (dogmatics) and with strong centres of leadership. It would thus be present in religions characterised by monotheism and dogmatism, that is to say, Christianity, and Catholicism, Islam and Judaism in particular. Hinduism and Buddhism would be almost entirely free of it. On the face of it, this argument may seem quite convincing, since-as mentioned above-a key element of fundamentalism in the political sense is a fundamentalist mindset, a belief in possessing the absolute truth.

\subsection{Absolute Truth and Fundamentalism}

Political and religious reality advocates caution, however, in unquestioningly accepting the above hypothesis. Certainly, absolutist claims to the truth and a strict order of power may be conducive to fundamentalist attitudes. Nevertheless, the religion which most explicitly carries absolutist claims-Catholicism - is not a particularly fertile soil for fundamentalism in the political sense of the term, despite the strict Catholic dogmatics, its monotheism, a single leader who provides the ultimate and binding interpretation of the truths of faith (see the dogma of papal infallibility in matters of faith and morals), as well as the hierarchical structure of power and subordination. Meanwhile, in the soil of Islam of Hinduism the phenomenon of fundamentalism thrives and prospers, even though they are religions without single dogmatics (in the case of Hinduism, it is even problematic to use the term orthodoxy), lacking a leader or even a single body to interpret the faith, with a scattered organisation of the faithful, and thus - as is sometimes said - much more democratic (Zenderowski and Wysocki 2014; Harrison 2008). One must thus conclude that the existence of absolute truth, or, to be more precise, belief in the universal validity and applicability of particular truths does not necessarily result in a kind of political fundamentalism. 
The logic that identifies belief in the truth with fundamentalism is open to considerable theoretical doubt. If it were to be accepted, the term fundamentalist would have to be applied to all those who claim that their convictions are universally applicable-for example, the advocates of human rights, or scientists. The obvious absurdity of such a solution shows that linking fundamentalism only to the recognition of truth is problematic to say the least. It would mean that scientists-who are particularly committed to rationally substantiating their opinions and developing the understanding of the truth they discover-would be a model example of a fundamentalist mindset characterised by limited openness to discussion.

The above findings suggest that we should reject the thesis that belief in universal truths present in a religious message represents in itself grounds for fundamentalism in the political sense. They also reveal another factor which may affect the fundamentalist potential of religion. Instead of faith in absolute truth, the criterion might be the relationship between faith and reason. A hypothesis may be proposed that fertile soil for fundamentalism may be provided by religions which not only claim to carry a universal truth (which is a constitutive element of nearly all religions as well as secular convictions concerning outlook), but which do not necessarily link it with the order of reason, or which are irrational by their very nature, and so, as pointed out by Gilles Kepel (1994), eluding the logic of reason. A doctrine more open to the ratio, in light of this hypothesis, would be less susceptible to becoming a soil for the "fundamentalist mindset" than a doctrine which says that the will of God or gods is not related to the category of rationality.

The above hypothesis may explain why so few fundamentalists are bred by Catholicism, while they thrive in the world of Islam and Hinduism, for example. This issue was mentioned by Benedict XVI during his well-known address in Regensburg. Citing the Byzantine emperor Manuel II Paleologus, he pointed out that it was obvious for the Christian emperor that violence was incompatible with the nature of God and the nature of the soul. He stressed that "[ $\mathrm{t}]$ he decisive statement in this argument against violent conversion is this: not to act in accordance with reason is contrary to God's nature" (Benedict XVI 2006). Referring to the comment of Theodore Khoury, who pointed out that "[f]or the emperor, as a Byzantine shaped by Greek philosophy, this statement is self-evident," he showed what he believed to be a fundamental difference between the Christian tradition, where God is presented as Logos (word, reason), and the Muslim tradition, where God is not bound by the norms of human rationality. Only in this latter perspective it is possible to go so far as to state, as did Ibn Hazn, that "God is not bound even by his own word, and that nothing would oblige him to reveal the truth to us. Were it God's will, we would even have to practise idolatry" (Benedict XVI 2006).

Christianity, as a religion of Logos (cf. J 1), did not encounter the Greek thought by chance, as pointed out by Benedict XVI who says: "The vision of Saint Paul, who saw the roads to Asia barred and in a dream saw a Macedonian man plead with him: 'Come over to Macedonia and help us!' (cf. Acts 16:6-10)— this vision can be interpreted as a 'distillation' of the intrinsic necessity of a rapprochement between Biblical faith and Greek inquiry" (Benedict XVI 2006). The originality of the work of Church Fathers consisted in the fact that they "fully welcomed reason which was open to the absolute, and they infused it with the richness drawn from Revelation" (John Paul II 1997, no. 41). From the perspective of the Catholic Church, this was not merely a meeting of cultures, but a metaphysical encounter; as John Paul II put it: a meeting "of creature and Creator." In its result, both faith and reason could rise, so to say, to a higher level: faith could build on reason, in which it found "a solid foundation for the perception of being, of the transcendent and of the absolute," as reason illuminated by faith is "set free from the fragility and limitations ... and finds the strength required to rise to the knowledge of the Triune God" (John Paul II 1997, no. 41 and 43). As a consequence of this encounter, it is not possible in the light of the Catholic doctrine to effectively separate faith from reason. This was most emphatically stated already by Saint Anselm, who wrote, "as the right order requires us to believe the deep things of Christian faith before we undertake to discuss them by reason; so to my mind it appears a neglect if, after we are established in the faith, we do not seek to understand what we believe" (Anselm of Canterbury 2005). 
This opening of faith to reason or, in fact, this fusion of faith and reason in the Catholic tradition also leads to a particular understanding of truth itself. Recognising the immutability of truth, the Catholic Church believes that truth is not static, it is not something that "we hold in our hands." Rather, it is seen as a gift from God, who keeps revealing himself to us. Consequently, its understanding is subject to continuous development, even though it is not subject to change. This conviction, present already in the first centuries of Christianity, is reflected well in a statement made by Saint Vincent, who explained, in the 5th century A.D., that "progress requires that the subject be enlarged in itself, alteration, that it be transformed into something else" (Vincent of Lerins 1894, no. 54). He therefore compared faithfulness to the truth of Revelation to a living organism, "which, though in process of years it is developed and attains its full size, yet remains still the same" (Vincent of Lerins 1894, no. 55). A similar statement was made by Vladimir Solovyov, who emphasised on the grounds of the Orthodox tradition: "Just at it would be foolish, not seeing the trunk or branches, leaves or flowers in the seed, to conclude that all of this is an artificial, external addition rather than a growth from the seed itself, and therefore to reject the entire future tree in order to only keep the seed; so it would be equally foolish to reject more sophisticated, that is to say, more developed forms of God's grace in the Church and to stubbornly seek to return to the form of the early Christian communities" (Solovyov 1988, p. 96).

It is worth stressing here that the synthesis of Biblical faith and Hellenic rationality, characteristic of Christianity, is manifested in different ways in its various currents. On the grounds of Christianity-together with Duns Scotus-the concept of voluntarism appeared and was later developed by Wilhelm Ockham, among others. It finally led to the claim that "we can only know God's voluntas ordinata. Beyond this is the realm of God's freedom, in virtue of which he could have done the opposite of everything he has actually done ... God's transcendence and otherness are so exalted that our reason, our sense of the true and good, are no longer an authentic mirror of God, whose deepest possibilities remain eternally unattainable and hidden behind his actual decisions" (Benedict XVI 2006). In Catholicism, this stance has never been accepted (Ockham himself was excommunicated by John XXII), and the Church has upheld its unequivocal belief in the "rationality" of God—the Logos. Ockham's logic has, however, left a significant mark on the Protestant tradition, which—through Martin Luther-embraces to a large extent the voluntarist view of God.

Educated in the spirit of nominalism, Luther radically dissented from Aristotle's philosophy, claiming that "he is to theology what darkness is to light. His ethics is the worst enemy of grace" (Maritain 1928, p. 15). In fact, he dissented from philosophy at large, claiming that reason was incompatible with faith (Maritain 1928, p. 16). Consequently, in practically all of its currents, Protestantism has criticised "philosophised theology" and—to a large extent deliberately-began the process of de-Hellenising Christianity (Szulakiewicz 2005, p. 184). As pointed out by Sławomir Springer, "Barth's battle against natural theology was a closure of the criticism, mounting since the times of F. Schleiermacher and Ritschl, which Evangelical theologians had raised against the traditional philosophical doctrine of God and against its use in the sphere of theology" (Springer 2010, p. 43). Worth mentioning is also the work of Adolf von Harnack, whose theology undermined the idea of dogma, seeing in it "the Greek spirit adopted by Christianity" (Szulakiewicz 2005, p. 186). Such an approach is a direct legacy of Luther, who, according to Maritain, claimed that "the use of reason in matters of faith, the claim to establish a coherent science of dogma ... by reasoning and the use of philosophy, in short, theology ... is an abominable scandal" (Maritain 1928, p. 16). We might add that even in those currents which do not advocate a liberal interpretation of the Scripture, Protestantism is marked by a "de-Hellenised" understanding of God. Let us take Søren Kierkegaard, for example, for whom "God is above morality" (Iwaszkiewicz 1972, p. XXXI) or, to refer to a less intellectually sophisticated interpretation of Protestantism, some of its American denominations marked by "an extremely anti-intellectual approach, only looking for an excuse to ... create a front between theology and science" (Życiński 1998, p. 24).

Once we recognise the diversity in approaches to rationality within Christianity, we can better understand the radical difference in the understanding of God we encounter in the context of Islam. 
The difference is already manifest in the fact that the Quran—as pointed out by Norman Daniel—a book believed to be dictated by Allah, has a status similar not so much to that of the Bible in Christianity, but to that of Jesus himself (Weigel 2009, p. 183). While in Christian tradition understanding of Revelation does not end with the letter of the Scripture (though, obviously, it may not contradict it), the Quran is more of a final and definitive decree of God's truth. This significantly contributes to the development of a belief in "possessing the truth," and-ultimately-the usurpation of "God's prerogatives" since its full and literal message has been placed "in our hands."

It seems of key importance, however, that in the Quran the (early) surahs which talk about mercy, peace, and tolerance, are found directly alongside the (later) ones which "advocate violence-violence directed against those who do not share the Muslim faith" (Kłodkowski 2006, p. 105). Consequently, although it is possible to claim that the Quran "accepts with approval both religious pluralism and diversity" (Ayoub 2007), according to the rule of abrogation (Sulkowski 2018) and in view of the status enjoyed by the Quran, the logic of Islam enables the adoption of a voluntarist view of God. In the Muslim context, today's jihadists or the ISIS fighters seem to be the faithful heirs of Ibn Hazn. As pointed out by George Weigel, the essence of their logic lies precisely in the identification of God as Absolute Will. Consequently, "jihadists are, within their own frame of reference, justified in believing that God can command anything —even the irrational. And so ... they believe that the murder of innocents is not simply morally acceptable, but morally required, if such murders advance the cause of Islam" (Weigel 2009, p. 59). In fact, the problem runs deeper, although it would be hard to challenge their interpretation of Islam based on the revelation of the Quran since it does not necessarily link God's will with the categories of human rationality.

A different kind of source for a voluntarist view of God is to be found in Hindu tradition. As it is well known, Hinduism is a religion of rich mythology, without consistent doctrine or even scriptural canon (Chiriyankadath 2010), which also means that is "paradoxical—often self-contradicting—in a number of ways on its foundational concept of God" (Zenderowski and Wysocki 2014, p. 8). Hindu mythology is understood "to have developed the idea of a divine triad in the earliest times that governs over everything. The triad emerged as an influence of the solar cults of India and had different deities in it during the Vedic Age. However, in the last thousand years of the Indian religious tradition, the universally governing triad has consisted of Brahma, Viśnū, and Śiva- 'the creator', 'the cherisher,' and 'the destroyer.' These three persons of the Godhead are coequal and are therefore worshipped as three faces of the same God. The Sanskrit expression for the Hindu triad is Tri Mūrtī Eko Deva, 'three faces, one God"' (Waqas 2015, pp. 9-10). The very fact that God could be at the same time a creator and a destroyer shows the challenge present in Hindu tradition to link God's will with the categories of human rationality, which inter alia refers to the law of no contradiction.

Even without going into detailed analysis of every religious tradition, the remarks above prove a need for critical reflection on the relation between belief in the absolute truth and fundamentalism in the political sense of that term. It seems that fertile soil for fundamentalism tends to be provided by religions which do not necessarily link their truths with the order of reason, grounding, in different ways, a voluntarist view of God rather than by belief in universal truth. Theory focused on relation between credo and ratio much better explains empirical observations, which suggests that the fundamentalist potential of Islam or Hinduism is profoundly higher than that of Christianity, and of Catholicism in particular.

\subsection{The Temporal Aspirations of Religion}

The reflection about the significance of the attitude to rationality for the emergence of fundamentalist movements needs an additional note, however. If we assume that the content of fundamentalism in all of its varieties is the idea of God's power, understood not in the perspective of eternity or the deep sense of historical events, but as actualised directly and fully in "this world," then the issue of key importance for the relationship between religion and fundamentalism is the relationship between religion and politics. It may thus be hypothesised that fertile soil for the development of 
fundamentalism is provided by religious doctrines which create an ideal, a utopia of social and political relations, supported by divine authority. At the same time, since at its sources fundamentalism is related to a hope of establishing a perfect world, a religion which introduces an eschatological distance to the temporal world will become a natural buffer against fundamentalist tendencies.

The difference between Islam and Christianity could be used as a case study. One specific feature of Islam is that it regularises the organisation of society and state (Zenderowski 2014). The dichotomy of regnum and sacerdotium, so crucial in the history of Western Christendom, has no equivalence there (Sulkowski 2018). Consequently, politics that represent a direct answer to religious commandments are, in a way, a natural form of the political. Without violating the structure of the relationship between religion and politics provided for in the Quran, it may legitimately be treated as a tool in creating a "model" world. Politics and religion are thus fused to a large extent through eschatology: politics may be treated as a tool for creating an ideal social and political order, contained in the religious formulas of the Quran and the tradition.

It is worth emphasising that such a stance is not only found in radical Islam. On the contrary, also liberal Muslim ideologists, who criticise traditional ulemas, object to the separation of the spiritual from the temporal. For example, for Mehdi Bazargan, one of the liberal leaders of the revolution in Iran, it was obvious that "there is no frontier between religion and politics. Religion must control and inspire politics, and not the contrary" (Keddie 2003, p. 199). Consequently, he criticises Christianity for being "unable to give believers directives for practical, social, and political life," referring them to "philosophic-political idols" (liberalism, socialism, etc.), "which Islam does not need, as it is a complete religion" (Keddie 2003, p. 199). A complete religion-for Islamic liberals, too-is a comprehensive one, providing solutions that are both temporal and eternal, whose natural environment is religious and political unity. Aware of this specificity of Islam, some scholars even propose that fundamentalism is inherent to Islam (Kłodkowski 2006, pp. 99-101).

Christianity, as Bazargan rightly points out, perceives the relationship between religion and politics differently. The Church, carrying internally the memory of Christ's death on a verdict issued by a governor of the Roman Emperor, as well as Christ distancing himself on many occasions from temporal power, believes that the Kingdom of God, or an ideal order, should not be expected or attempted here on earth. Consequently, the Church perceives identification of the state and religion as a temptation which, if succumbed to, would be as harmful to the state as it would be to religion (Mazurkiewicz 2012). In this perspective, it is easy to understand why, in their reflection on law, "Christian theologians aligned themselves against the religious law associated with polytheism and on the side of philosophy, and that they acknowledged reason and nature in their interrelation as the universally valid source of law."(Benedict XVI 2011) It is not an exaggeration, therefore, to say that the central idea of modern democracies, namely the idea of the rule of law, is an outcome of the supra-religious approach, developed on Christian grounds, to the foundations of legal order (Gierycz 2012).

The Christian approach to politics is anchored in the belief that man, created in the likeness and image of God, participates in God's wisdom by his very nature through reason. By virtue of this participation, he is able to recognise and strive towards objective good (Thomas 1947, p. 2270). This participation does not depend on faith (cf. Romans 2,14-15) but results from the very nature of man-within himself, he discovers an inner law which is "natural" to him, inherent to the human condition (John Paul II 1993, no. 43).

The reference to natural law does not make religion irrelevant. Christian tradition is fully aware, as expressed already by Cicero (The Republic), of man's freedom in violating or obliterating this law within himself. As Thomas Aquinas says, although the "natural law, in the abstract, can nowise be blotted out from men's hearts," "it is blotted out in the case of a particular action, in so far as reason is hindered from applying the general principle to a particular point of practice, on account of concupiscence or some other passion ... by evil persuasions ... or by vicious customs and corrupt habits...and even unnatural vices" (Thomas 1947, p. 2308). Christianity is also aware that God is the one who should be asked about good (see Mark 10:17-27); that there is a need of higher that human 
being authority to resolve moral dilemmas; that revelation brings knowledge about what is the good proper to man and is the point of reference for properly forming one's conscience. Thus, emphasising that the state does not "create" good, "Christianity maintains that the objective norms governing right action are accessible to reason, prescinding from the content of revelation. According to this understanding, the role of religion in political debate is not so much to supply these norms, as if they could not be known by non-believers-still less to propose concrete political solutions, which would lie altogether outside the competence of religion-but rather to help purify and shed light upon the application of reason to the discovery of objective moral principles" (Benedict XVI 2010). Such a role of Christianity, pointed out in similar ways by secular thinkers (Habermas 2005; Perra 2005), shows that in the case of Christianity, religion is not a political factor but rather "external" to politics and a source which the political community may draw on for moral truth. Consequently, politics and religion within the Christian tradition are linked not by eschatology, but by ethics (Gierycz 2012; Mazurkiewicz 2007). Religion thus becomes a buffer that safeguards respect for human dignity in the political order.

\section{Conclusions}

The above analyses have essentially, though not all in the same way, confirmed the legitimacy of the three hypotheses made at the outset.

From the perspective of political science, it seems no longer possible to maintain that fundamentalism is a strictly religious phenomenon. Both the studies into religious fundamentalism analysed and documented manifestations of secular fundamentalism lead to the conclusion that it is simply a specific way of thinking and acting which may develop and thrive just as well in secular as in religious soil. Its specific feature is the aspiration, anchored in an absolutist, selective and Manichean mindset, to establish an ideal order, which even justifies the use of violence. Fundamentalism as such is not necessarily related to religion, and —as demonstrated by history — has also thrived in atheist and anti-religious systems.

Additionally, the second hypothesis, namely that secularisation contributes to both secular and religious fundamentalist tendencies, has proved to be well-substantiated. As has been demonstrated, while secularisation in the West generates reactions of angry religiousness in other cultures (e.g., Islam or Hinduism), in the context of Western culture it contributes to the development of secular fundamentalisms, supporting the idea of unconstrained politics, and thus the hope for immanentising salvation, too. In this aspect, the analyses presented above suggest that it is necessary to broaden the meaning of the traditional modernisation hypothesis which considers only religious fundamentalism to be a reaction to the process of secularisation.

With regards to the third hypothesis, it should be noted that-on the theoretical level-the above analyses have confirmed that religion potentially represents a unique safeguard against fundamentalism, with practically nothing to substitute for it. By providing an ethical grounding for the political order, particularly by warranting an eschatological distance from political issues, it prevents the kingdom of man being confused with the kingdom of God, thus discarding the fundamentalist logic at its very roots. At the same time, the analyses have revealed two key conditions which must be satisfied if a religion is to provide such a barrier: firstly, it must understand itself as a rational religion; and secondly, it must clearly distinguish spiritual from secular power. Consequently, the analyses have shown that, regarding the actual role of religion as a safeguard against fundamentalism, the hypothesis is a medium-range claim, explaining in the contemporary context-in relation to the major religious traditions-first of all the role of Christianity, especially Catholicism, with respect to fundamentalist tendencies. In fact, the religions of the world are religions of reason to a very different degree, and they are often not interested in introducing a separation between spiritual and secular power. The above analyses have shown that, in the context of Islam where the vision of God is largely arbitrary and unpredictable, and where religion and politics are closely intertwined, fundamentalism could be, essentially, a natural product of the religious tradition. In the context of Western Christianity, where the separation between secular and spiritual power is—generally—an obvious principle, a different 
attitude to reason in religion may explain the higher fundamentalist potential of Protestantism than of Catholicism.

Funding: This research received no external funding.

Conflicts of Interest: The author declares no conflict of interest.

\section{References}

Almond, Gabriel A., Emmanuel Sivan, and R. Scott Apleby. 1995. Fundamentalism: Genus and Species. In Fundamentalism Comprehended. Edited by Martin E. Marty and R. Scott Appleby. Chicago and London: University of Chicago Press, pp. 399-424.

Anselm of Canterbury. 2005. Cur Deus Homo? Morrisville: Lulu.com.

Armstrong, Karen. 2000. The Battle for God: Fundamentalism in Judaism, Christianity and Islam. New York: Random House Publishing Group.

Armstrong, Karen. 2004. Fundamentalism and the Secular Society. International Journal: Canada's Journal of Global Policy Analysis 59: 875-77. [CrossRef]

Aron, Raymond. 1962. The Opium of the Intellectuals. Translated by Terence Kilmartin. New York: W. W. Norton and Company.

Aronson, Elliot, Timothy Wilson, and Robin M. Akert. 1994. Social Psychology: The Heart and the Mind. New York: HarperCollins College Division.

Ayoub, Mahmoud. 2007. A Muslim View of Christianity: Essays on Dialogue. Edited by Irfan A. Omar. New York: Orbis Books.

Benedict XVI. 2006. Faith, Reason and the University-Memories and Reflections. Lecture in Regensburg. Available online: http://w2.vatican.va/content/benedict-xvi/en/speeches/2006/september/documents/hf_benxvi_spe_20060912_university-regensburg.html (accessed on 27 January 2020).

Benedict XVI. 2007. Encyclical Letter Spe salvi to the Bishops, Priests and Deacons, Men and Women Religious, and All the Lay Faithful. Available online: http://w2.vatican.va/content/benedict-xvi/en/encyclicals/documents/ hf_ben-xvi_enc_20071130_spe-salvi.html (accessed on 17 January 2020).

Benedict XVI. 2010. Speech in Westminster Hall. Available online: https://www.bbc.com/news/uk-11352704 (accessed on 20 January 2020).

Benedict XVI. 2011. The Listening Heart. Reflections on the Foundations of Law. Address during a visit to the Bundestag. Available online: http:/w2.vatican.va/content/benedict-xvi/en/speeches/2011/september/ documents/hf_ben-xvi_spe_20110922_reichstag-berlin.html (accessed on 17 January 2020).

Berlin, Isaiah. 1950. Political Ideas in the Twentieth Century. Foreign Affairs 28: 351-85. [CrossRef]

Bielefeldt, Heiner, and Wilhelm Heitmeyer. 1998. Politisierte Religion: Ursachen und Erscheinungsformen des modernen Fundamentalismus. Frankfurt am Main: Suhrkamp.

Bock-Cote, Matthieu. 2017. Multikulturalizm jako religia polityczna. Translated by Marek Chojnacki. Warszawa: PAX.

Bruce, Steve. 2000. Fundamentalism. Cambridge: Polity Press.

Carr, Edward Hallet. 1951. Bolshevik Revolution 1917-1923. Baltimore: Penguin Books, vol. 1.

Casanova, Jose. 1994. Public Religions in the Modern World. Chicago: University of Chicago Press.

Chesterton, Gilbert Keith. 2017. Biographies. Scotts Valley: CreateSpace.

Chiriyankadath, James. 2010. Hinduism. In Routledge Handbook on Religion and Politics. Edited by Jeffrey Haynes. New York: Routledge, pp. 79-91.

Cowden, Stephen, and Gita Sahdal. 2017. Why fundamentalism? Feminist Dissent 2: 7-38. [CrossRef]

Dorosz, Krzysztof. 2010. Bóg i terror historii. Warszawa: Semper.

Gellner, Ernst. 1992. Postmodernism, Reason and Religion. London and New York: Routledge.

Gierycz, Michał. 2012. Chrześcijaństwo i podstawy polityki. Chrześcijaństwo-Świat-Polityka 13: 26-32. Available online: http://www.chsp.waw.pl/images/wydania/2012/13_MG.pdf (accessed on 20 January 2020). [CrossRef]

Gierycz, Michał. 2017. Europejski spór o człowieka. Studium z antropologii politycznej. Warszawa: Wydawnictwo Naukowe UKSW.

Gierycz, Michal. 2019. Overcoming Reductionism. On "In-depth" Systems Analysis in the Political Science of Religion. Christianity-Word-Politics 23: 41-65. Available online: https://czasopisma.uksw.edu.pl/index.php/ csp/article/view/3641 (accessed on 20 January 2020). [CrossRef] 
Gray, John. 2007. Al Qaeda and What It Means to be Modern. London: Faber and Faber.

Habermas, Jurgen. ; Translated by Kaniowski Andrzej. 2005. Religia w sferze publicznej. Krytyka Polityczna 9/10: 240-51.

Hallermann, Herbert, Thomas Meckel, Michael Droege, and Heinrich de Vaal. 2019. Lexikon für Kirchen-und Religionsrecht. Band 2. Padeborn: Ferdinand Schöningh, p. $105 \mathrm{f}$.

Harrison, Victoria. 2008. Modernity, religious fundamentalism and the secularization thesis. The Icefai University Journal of History and Culture 2: 7-21.

Haynes, Jeffrey. 2010. Religious Fundamentalisms. In Routledge Handbook of Religion and Politics. Edited by Jeffrey Haynes. New York: Routledge, pp. 159-173.

Iwaszkiewicz, Jarosław. 1972. Od tłumacza. In Bojaźn i drżenie. Choroba na śmierć. Edited by Soren Kirkegaard. Warszawa: PWN, pp. IX-XXXIX.

Janicki, Mariusz, and Wiesław Władyka. 2015. Katolicyzm polityczny. Polityka 2968: 15. Available online: http://www.polityka.pl/tygodnikpolityka/kraj/1586895,1,fundamentalisci-z-pis-szykuja-sie-dowladzy.read (accessed on 17 January 2020).

Jansen, Jonatan. 1997. The Dual Nature of Islamic Fundamentalism. New York City: Cornell University Press.

John Paul II. 1991. Encyclical Letter Centesimus Annus to His Venerable Brother Bishops in the Episcopate, the Priests and Deacons, Families of Men and Women Religious, all the Christian Faithful, and to All Men and Women of Good Will on the Hundredth Anniversary of Rerum Novarum. Available online: https://w2.vatican. va/content/john-paul-ii/en/encyclicals/documents/hf_jp-ii_enc_01051991_centesimus-annus.html (accessed on 17 January 2020).

John Paul II. 1993. Encyclical Letter Veritatis Splendor Addressed by the Supreme Pontiff Pope John Paul II to all the bishops o the Catholic Church regarding certain fundamental questions of the Church's moral teaching. Available online: http://www.vatican.va/content/john-paul-ii/en/encyclicals/documents/hf_jp-ii_ enc_06081993_veritatis-splendor.html (accessed on 17 January 2020).

John Paul II. 1997. Encyclical Letter Fides et ratio of the Supreme Pontiff John Paul II to the Bishops of the Catholic Church on the Relationship Between Faith and Reason. Available online: http://w2.vatican.va/content/johnpaul-ii/en/encyclicals/documents/hf_jp-ii_enc_14091998_fides-et-ratio.html (accessed on 17 January 2020).

Kant, Immanuel. ; Translated by Mary C. Smith. 1784. What is Enlightenment. Available online: http: //www.columbia.edu/acis/ets/CCREAD/etscc/kant.html (accessed on 20 January 2020).

Keddie, Nikki R. 2003. Modern Iran: Roots and Results of Revolution. New Haven: Yale University Press.

Kepel, Gilles. 1994. The Revenge of God: The Resurgence of Islam, Christianity and Judaism in the Modern World. Pennsylvania: Pennsylvania State University Press.

Kijas, Zdzisław. 2010. Fundamentalizm i ponowoczesność wobec prawdy. In Postmodernizm i fundamentalizm a prawda. Od idei do praxis. Edited by Halina Grzmil-Tylutki and Agnieszka Hennel-Brzozowska. Kraków: Jagiellonan Univeristy, pp. 15-24.

Kłoczowski, Jan A OP. 2004. Religia. In Słownik społeczny. Edited by Bogdan Szlachta. Kraków: WAM, pp. $1063-80$.

Kłodkowski, Piotr. 2006. O pęknięciu wewnatrz cywilizacji. Warszawa: Dialog.

Kołakowska, Agnieszka. 2010. Wojny Kultur i inne Wojny. Warszawa: Teologia polityczna.

Lenin. 1918. The State and Revolution. Available online: https://www.marxists.org/ebooks/lenin/state-andrevolution.pdf (accessed on 17 January 2020).

Marczewska-Rytko, Maria. 2007. Religious Fundamentalism: Theoretical Problems. Polish Political Science XXXVI: 215-23.

Maritain, Jacques. 1928. Three Reformers: Luther, Descartes, Rousseau. London: Sheed \& Ward.

Mazurkiewicz, Piotr. 2007. Eschatologia—etyka-polityka. Chrześcijaństwo-Świat-Polityka 2: 29-32. Available online: http://www.chsp.waw.pl/images/wydania/2007/3_PM.pdf (accessed on 20 January 2020).

Mazurkiewicz, Piotr. 2012. Polityczna niepolityczność Kościoła. Chrześcijaństwo-Świat- Polityka 13: 5-20. Available online: http://www.chsp.waw.pl/images/wydania/2012/13_PM.pdf (accessed on 20 January 2020). [CrossRef]

Mazurkiewicz, Piotr, and Michał Gierycz. 2016. Europäische Anthropologie und europäische Politik. Beobachtungen in der Gegenwart. In Europa und die Anthropologie seiner Politik. Der Mensch als Weg der Geschichte-Zur Philosophie Karol Wojtylas. Edited by Christoph Bohr and Christian Schmitz. Berlin: Berliner Wissenschafts-Verlag, pp. 133-76. 
Ozzano, Luca. 2009. Religious Fundamentalism and Democracy. Politics And Religion 1 III: 127-53.

Perra, Marcello. 2005. Wprowadzenie. In Europa Benedykta w kryzysie kultur. Edited by Joseph Ratzinger. Translated by Wiesława Dzieża. Częstochowa: Święty Paweł, pp. 21-37.

Pratt, Douglas. 2020. Religious Fundamentalism: A Paradigm for Terrorism? Australian Religion Studies Review (pre-published). Available online: https://www.researchgate.net/publication/250014440_Religious_ Fundamentalism_A_Paradigm_for_Terrorism (accessed on 17 January 2020).

Ratzinger, Joseph. 2005. Europe in the Crisis of Cultures. Communio 32: 345-46. Available online: https: //www.theway.org.uk/endeanweb/ratzinger32-2.pdf (accessed on 20 January 2020).

Rausch, Cassandra. 2015. Fundamentalism and Terrorism. Journal of Terrorism Research 6: 2. [CrossRef]

Riesebrodt, Martin. 2004. Was ist "religioeser Fundamentalismus"? In Religioeser Fundamentalismus. Vom Kolonialismus zur Globalisierung. Edited by Clemens Six, Martin Riesebrodt, Siegfried Hans and Wien Innsbrueck. München and Bozen: Studien Verlag, pp. 13-32.

Sacks, Jonathan. 1991. The Persistence of Faith: Religion, Morality and Society in Secular Age. London: Weidenfeld \& Nicolson.

Scheler, Max. 1921. Vom Ewigen in Menchen. Ersten Band Religiose Erneuerung. Leipzig: Der Neue Geist.

Schlegel, Jean-Louis. 2003. La loi de Dieu contre la liberté des hommes: Intégrismes et fondamentalismes. Paris: Le Seuil. Solovyov, Vladimir. 1988. Wybór pism. Poznań: PIW, Volume 1.

Sowell, Thomas. 2007. A Conflict of Visions. Ideological Origins of Political Struggles. New York: Basic Books. Spaemann, Robert. 2012. Kroki poza siebie. Translated by Jarosław Merecki. Warszawa: Oficyna Naukowa.

Springer, Sławomir. 2010. Protestancka myśl teologiczna w obliczu krytyki filozoficznej. Przegląd Religioznawczy 2: 41-50.

Sulkowski, Mariusz. 2018. Ideologia Państwa Islamskiego. Chrześcijaństwo - Świat - Polityka 22: 211-30. Available online: https://czasopisma.uksw.edu.pl/index.php/csp/article/view/3230 (accessed on 20 January 2020). [CrossRef]

Szulakiewicz, Marek. 2005. Osoba i chrześcijaństwo w okresie dehellenizacji współczesnej kultury. Filozofia chrześcijańska 2: 177-92.

Thomas, Aquinas. ; Translated by Fathers of the English Dominican Province, and Benziger Bros. 1947. Summa Theologica. Available online: https://www.ccel.org/a/aquinas/summa/cache/summa.pdf (accessed on 20 January 2020).

Tibi, Bassam. 1997. Fundamentalizm Religijny. Translated by Janusz Danecki. Warszawa: PIW.

Vanberg, Victor. 1987. Conflict of Visions. Thomas Sowell. Cato Journal 7: 547-50.

Vincent of Lerins. ; Translated by C.A. Heurtley. 1894. Commonitorium. Available online: http://www.newadvent. org/fathers/3506.htm (accessed on 20 January 2020).

Voegelin, Eric. 1975. From Enlightenment to Revolution. Durnham: Duke University Press.

Voegelin, Eric. 2000. Political Religions. In The Collected Work of Eric Voegelin. Volume 5: Modernity without Restraint. Translated by Virginia Ann Schildhauer. Columbia: University of Missouri Press, pp. 19-73.

Waqas, Syed M. 2015. Jewish and Hindu Beliefs and Thought Patterns. Comparing and Contrasting Various Aspects of the Two Most Ancient Religions of the World. Cincinnati: Department of Biblical Studies, Cincinnati Christian University, Available online: https:/www.researchgate.net/publication/328943327_JEWISH_AND_HINDU_ BELIEFS_AND_THOUGHT_PATTERNS_Comparing_and_Contrasting_Various_Aspects_of_the_Two_ Most_Ancient_Religions_of_the_World (accessed on 20 January 2020).

Wass, Adam S. V. D. 2006. Bracia Muzułmanie w Jordanii. Doktryna i organizacja Bractwa na przełomie XX $i$ XXI wieku. Lublin: Towarzystwo Naukowe KUL.

Weigel, George. 2009. Faith, Reason and the War against Jihadism. New York City: Random House.

Wnuk-Lipiński, Edmund. 2004. Świat międzyepoki. Globalizacja. Demokracja. Państwo narodowe. Kraków: Znak.

Zdybicka, Zofia. 2006. Człowiek i religia. Lublin: Towarzystwo Naukowe KUL.

Zenderowski, Radosław. 2014. Islam. In Religia i polityka. Zarys problematyki. Edited by Piotr Burgoński and Michał Gierycz. Warszawa: Elipsa, pp. 67-99.

Zenderowski, Radosław, and Artur Wysocki. 2014. Hinduizm. In Polityka i religia. Zarys problematyki. Edited by Piotr Burgoński and Michał Gierycz. Warszawa: Elipsa, pp. 128-52. 
Życiński, Józef. 1998. O nauce i wierze. In Rozmowy na koniec wieku 2. Edited by Katarzyna Janowska and Roman Mucharski. Kraków: Znak, pp. 21-34.

(C) 2020 by the author. Licensee MDPI, Basel, Switzerland. This article is an open access article distributed under the terms and conditions of the Creative Commons Attribution (CC BY) license (http://creativecommons.org/licenses/by/4.0/). 